\title{
Human Caused Mortality in the Leopard (Panthera pardus) Population of Nepal
}

\author{
Tej B. Thapa \\ Central Department of Zoology, \\ Tribhuvan University, Kirtipur, Kathmandu, Nepal, \\ Email: tbthapa@cdztu.edu.np
}

\begin{abstract}
Estimating cause specific leopard (Panthera pardus) mortality is critical to their conservation. This paper examined leopard death reports during 2006-2013 in order to estimate cause-specific mortality, identify conservation issues related to leopard mortality and provide recommendations for reducing human-caused mortality in Nepal. Data revealed that the leopards in the human dominated landscape are susceptible to variation in survival caused by human induced mortality $(65 \%)$, with retaliation $(31 \%)$ and lethal control $(20 \%)$ of declared problem leopard as a significant part. Elevated human induced mortality can cause large scale stochasticity influencing population dynamics of leopard. The conservation of leopards needs to acknowledge strategies to limit retaliatory killings and lethal control in the plans, while addressing its conflicts with human. Efforts to reduce human-caused mortality should focus on reducing poaching and deaths from human-leopards conflicts.
\end{abstract}

Keywords: Human caused mortality, leopard population, retaliation, lethal control, conservation

\section{INTRODUCTION}

Knowledge on the causes of mortality are important parameter in understanding population dynamics of large carnivore. Mortality data provide an opportunity to assess whether observed mortality rates are sustainable and insight into ways to reduce mortality (Goodrich et al. 2008). Human caused mortality is one of the greatest threats to the survival of carnivore population worldwide (Noss et al. 1996; Woodroffe \& Ginsberg, 1998; Woodroffe, 2001). Future population of these species depend on the survival of breeding adults (Weaver et al. 1996), but human-caused mortality often takes a heavy toll on this cohort (Fuller, 1989; Mclellan et al. 1999). Even small scale changes in adult survivorship may have serious consequences for persistence of large carnivores because they are at the top of food chain; have large home range and sparse distribution. Long-term survival of adults, especially females, is critical to population well-being of the large carnivore (Knight \& Eberhardt, 1985; Weaver et al. 1996).

Leopards are most widely ranging and most versatile big cat species (Bailey, 1991). They occur at low densities in human dominated landscape due to low prey biomass and have large area requirements (Nowell \& Jackson, 1996; WII, 2007). On these unprotected landscape, humanleopard conflicts and associated mortality are common (Henschel et al. 2008; Athreya, 2012). Like other big carnivores (Woodroffe \& Ginsberg, 1998; Gaona et al. 1998; Haight et al. 1998; Carroll et al. 2004, Neilsen et al.
2006), leopard populations are sensitive to unnatural death (Blame \& Hunter, 2004), thus it is important to estimate causes of mortality. No published data exist on leopard mortality in Nepal. In this context, this study attempts to estimate cause-specific mortality status and also discuss conservation issues related to leopard mortality of Nepal. The data used in this study is limited because it relies on the reports, and leopards killed as human- leopard conflicts are often reported whereas poached or poisoned animals may not be detected properly. Natural deaths of this elusive species are rarely noticed.

\section{MATERIALS AND METHODS}

Wildlife conservation and protected area system (PAS) in Nepal is regulated by National Park and Wildlife Conservation Act 1973. Currently, over 23percent of the areas are under protected in Nepal, belonging to four main categories: National Parks, Wildlife Reserves, Hunting Reserve, Conservation Areas and Buffer Zones (Fig. 1).

Data on leopard death were collected from the Government offices (Department of National Park and Wildlife Conservation- the government agency responsible for protection and management of all wildlife, and District Forest Offices). In addition news reports published in daily news papers and literatures were through reviewed. Data logged at Chitwan National Park (CNP), Bardia National Park (BaNP), Banke National Park (BaNP), Parsa Wildlife Reserve (PWR), Suklaphanta Wildlife 
Reserve (SWR), Annapurna Conservation Area (ACA), Regional Forest Directorate of Western Developmental Region (Pokhara) and District Forest Offices of Chitwan, Nawalparashi, Rupandehi, Banke, Bardia and Kaski were collected through the visit of respective offices. During visit to these offices, interactions were also made with the officials to discuss issues of leopard mortality. Killings of wildlife species are illegal in Nepal, therefore any offense to them are registered at offices of Protected Areas and District Forest Offices and then the information sent to centre at the Department of National Park and Wildlife Conservation. Similarly, the wildlife offense cases are covered by news papers also. However, the analysis was based only on verified leopard death cases.

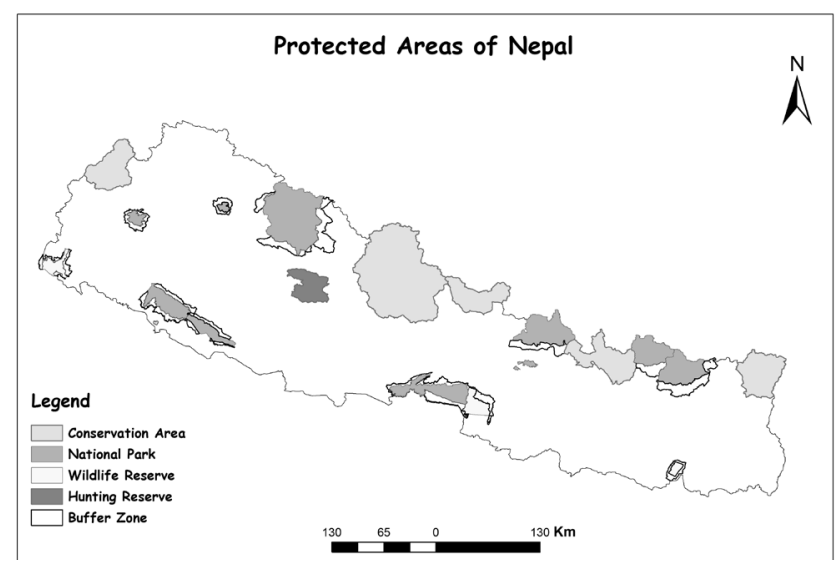

Fig. 1. Map of Nepal showing protected area system of Nepal.

Mortalities were first classified as natural, humancaused and unknown cause. Deaths were classified as natural when a death caused by starvation, disease, old age, violent interaction with other leopard, etc. natural cause was evident. Mortalities classified as humancaused were further categorized by the apparent reason: (1) lethal control of problem animals (leopard destroyed by government in response of series of human killing or threats); (2) retaliation (i.e., leopard being killed by local people); (3) accident such as vehicle collision (i.e., leopard carcass found at the road showing violent death) and (4) poached (i.e., the leopard killed illegally). Death was categorised unknown, when cause could not be determined. Mortality data was categorised on the basis of age as cub, subadult and adult (Sunquist, 1981) and sex.

\section{RESULTS}

\section{Causes of mortality}

A total of 51 leopards were confirmed died during 2006 to 2013 (Table 1). Sixty five percent of all confirmed death was human caused. Retaliation (31\%) and lethal control $(20 \%)$ of leopards involved in conflicts with human were the most prevalent sources of human-caused mortality. Other sources included poaching $(n=4)$ and collisions with vehicles $(n=3)$. Thirty five percent (18) of total recorded deaths were possibly occurred due to natural causes.

Table 1. Mortality causes of Leopard in Nepal, based on confirmed report from 2006 to 2014

\begin{tabular}{|c|c|c|c|c|c|c|}
\hline \multirow{2}{*}{ Year } & \multicolumn{7}{|c|}{ Causes of death during 2006 to 20013 } \\
\cline { 2 - 7 } & Natural & $\begin{array}{c}\text { Lethal } \\
\text { control }\end{array}$ & Poaching & Retaliation & $\begin{array}{c}\text { Road } \\
\text { accident }\end{array}$ & Total \\
\hline 2006 & 1 & 0 & 3 & 0 & 0 & 4 \\
\hline 2007 & 0 & 1 & 0 & 0 & 0 & 1 \\
\hline 2008 & 0 & 0 & 0 & 1 & 0 & 1 \\
\hline 2009 & 0 & 0 & 0 & 1 & 0 & 1 \\
\hline 2010 & 3 & 3 & 0 & 1 & 0 & 7 \\
\hline 2011 & 3 & 2 & 0 & 3 & 1 & 9 \\
\hline 2012 & 7 & 0 & 1 & 3 & 1 & 12 \\
\hline 2013 & 4 & 4 & 0 & 7 & 1 & 16 \\
\hline Total & 18 & 10 & 4 & 16 & 3 & 51 \\
\hline
\end{tabular}

Age and sex of dead leopards

Of the 51 leopards, about 45 percent were adults, 31 percent sub-adults and 8 percent cubs, but the age of 16 percent dead leopards were not available. Among the dead leopards, more females were died than male in adult, but in case of subadult and cub more males were died than females (Fig. 2). Human- caused mortality was highest among the sub-adult (79\%) followed by adult (57\%) and cub $(50 \%)$. Similarly, 43 percent dead individuals were male and 41 percent were female leopards and reaming dead animals were unknown interns of sex.

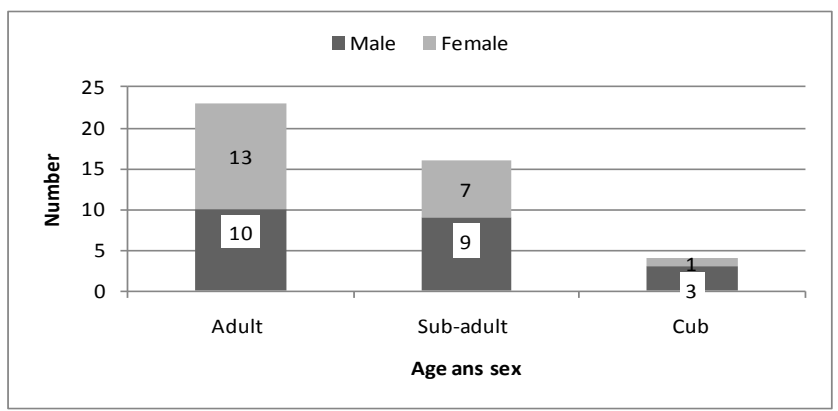

Fig.2. Age and sex of dead leopards

Leopard mortality was higher in the month of April and during December- February, while low number of deaths was observed low during July- September (Fig. 3 ). Among the leopard that killed by humans, about 48 percent was adults, 45 percent sub-adults and another 6 percent cubs (Fig. 4). Of the 33 individual died by human cause, nearly 50 percent killed by people in retaliation 
of actual or perceived threat, 10 individuals shot by government order as problem animal, 12 percent killed by poachers and remaining 9 percent leopard died due to road accident.

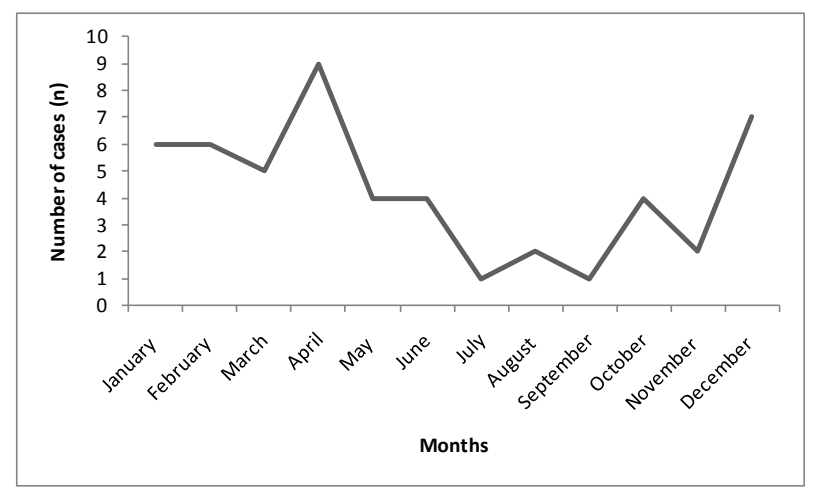

Fig. 3. Number of leopard died from different causes in Nepal (2006- 2013).

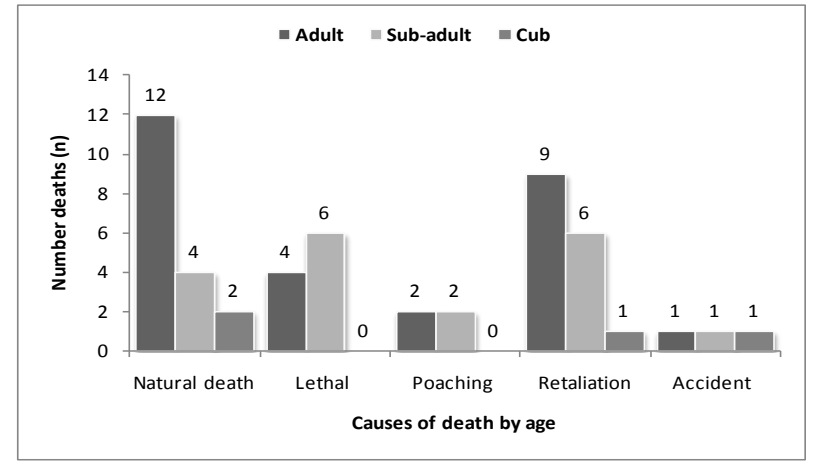

Fig. 4. Cause specific of leopard death by different age group

\section{Spatial distribution of leopard death}

Leopard death cases were recorded from 18 different districts. Maximum cases occurred at Kathmandu district $(n=8)$, followed by Nuwakot $(n=7)$, Kaski $(n=6)$, Bardia $(n=4)$, Kailali $(n=4)$ and Syangja $(n=4)$. Other districts where incidence of leopard death recorded are Bhaktapur, Tanahun, Baglung, Chitwan, Gulmi, Kabhre, Myagdi, Parbat, Rautahat and Solukhumbu.

\section{DISCUSSION}

Despite limitations with data, this study shows the human induced mortality of leopards in Nepal is a widespread problem. Data revealed that at least $65 \%$ reported leopard mortality was human caused. Thapa (2011) reported over $70 \%$ of recorded leopard mortality caused by anthropogenic factors in Chitwan. The actual killing rates probably higher than these estimates because human caused leopard death is difficult to record in many rural areas. Similar high mortality rates of big cats from anthropogenic causes have been reported elsewhere
(Chetkiewicz \& Raygorodetsky, 1999; Carvalho \& Pezzuti, 2010; Ramalho, 2012). Effective management of protected areas does not guarantee the conservation of this felid in Nepal. Although, there is no estimates for leopard population and its trend in Nepal except Chitwan National Park (Thapa, 2011), but human caused mortality may have driven a decline in leopard abundance.

\section{Human caused mortality}

Retaliatory killing in response to livestock depredation and human attacks was the single most important cause of mortality for adult and sub-adult leopards. Retaliatory killing occurs across the leopard range, but it is correlated with human attacks and livestock depredation (Shah et al. 2004; Kissui 2008; Ikanda \& Packer, 2008). High rates of retaliation are common among large cat species (Bauer et al, 20081; Packer et al. 2011) and are major threats for their survival (Stahl \& Vandel, 1999, Andren et al. 2006). Nonetheless, it is clear that conflict is an important cause of mortality. Another important human caused mortality of leopard is lethal control of declared problem leopards. Both retaliation and lethal control of problem leopard related with real or perceived threats of leopard on human lives and livestock. Poaching and road accidents are other cause of leopard mortality. In the view of current law enforcement capacity, habitat degradation, prey depletion and extension of road network, poaching and road accident can be major challenge in future.

Both adult and sub- adult leopards were vulnerable for human induced death. Data on sex ratio of human induced mortality indicates almost equal number of death of both sexes. However, a female bias sex ratio is expected under the classic cat social organization in which the larger home range of male overlaps with the smaller ranges of multiple females (Sunquist, 1981; Smith, 1993; Nowell \& Jackson, 1996; Jenny 1996; Karanth \& Chundawat, 2002; Oden \& Wegge, 2005; Harmsen, 2006), therefore death of more female is expected in specific area. But because of larger home range and mobile nature, the males probably encountered and attacked to human and more death in retaliation than female.

Elevated human-caused mortality of female and subadults, can affect population structure and spatial ecology in human dominated landscape. The human induced mortality have been found to affect inter population vital rates with consequences for local and regional populations (Newby et al. 2013). Inter population dynamics, and their population consequences depend on the characteristics of dispersal including emigration, dispersal distance, and establishment success (Bowller $\&$ Benton, 2005). Dispersal is essential to maintaining genetic connectivity within the population of leopards, but elevated human-caused mortality reduces ecological dispersal (Newby et al. 2013). 
Data on human caused leopard mortality revealed that problems are more acute in the human dominated landscapes: hill districts and urban areas, and currently its population safe only in the protected areas. Most leopard populations live in human dominated landscape, often alongside humans and feeding on livestock and dogs (Sedeisnsticker et al. 1990; Mukharjee \& Mishra, 2001; Edgaonkar \& Chellam, 2002; Thapa, 2011). Large carnivores, living mostly outside protected areas, accidental or intentional killing by people drives local extinction or reduces their numbers (Noss et al. 1996; Woodroffe \& Ginsberg, 1998; Blame \& Hunter, 2004, Joshi \& Agarwal, 2012). High human caused mortality might affect source-sink dynamics of leopards, almost all the recorded mortality occurred in non protected areas and protected areas are generally considered as source population. High rates of mortality in a dispersal habitat patch (sink) could lead to reduced population growth in a source habitat (Gundersen et al. 2001).

\section{CONCLUSION}

This study clearly revealed that leopard populations in Nepal are subject to high human caused mortality and such an elevated unnatural death probably reduced dispersal (emigration, dispersal distance, and establishment) and can affect population structure and spatial ecology of leopards in human dominated landscape. In cat society, female have reduced emigration rates, greater philopatry, shorter dispersal distances and an overall reduction in the extent of inter population exchange under elevated human-induced mortality. Hence, humancaused mortality can have important consequences on leopard population dynamics. Therefore, there needs conservation actions that must included changes in national legislation to enlist leopard under the protected species category, development of leopard conservation program and addressing human- leopard conflict. Estimating nationwide population and rates of mortality and survival are preliminary steps for the long term conservation of leopard in Nepal.

\section{ACKNOWLEDGEMENTS}

The author is grateful to DNPWC and different District Forest Offices for providing data logged in their offices and actively participated in the interaction.

\section{REFERENCES}

Andren, H., Linnell, J.D.C., Liberg, O., Andersen, R., Danell, A., Karlsson, J., Odden, J., Moa, P.F., Ahlqvist, P., Kvam, T., Franzen, R. and Segerstro“m, P. 2006. Survival rates and causes of mortality in Eurasian lynx (Lynx lynx) in multi-use landscapes. Biological Conservation 131: 23-32.

Balme, G., and Hunter, L. 2004. Mortality in a protected leopard population, Phinda Private Game Reserve, South Africa: A population in decline? Ecological
Journal 6: 1-6.

Bauer, H., Nowell, K. and Packer, C. 2008. Panthera leo. IUCN red list of threatened species. Version 2010.1. International Union for Conservation of Nature, Gland, Switzerland. Available from http:// www.iucnredlist.org/apps/redlist/details/15951/0 (accessed Dec 2013).

Bowler, D. E. and Benton, T.G. 2005. Causes and consequences of animal dispersal strategies: relating individual behaviour to spatial dynamics. Biol. Rev. 80: 205-225.

Carroll, C., Noss, R. F., Pacquet, P. C. and Schumaker, N. H. 2004. Extinction debt of protected areas in developing landscapes. Conservation Biology 18:1110-1120.

Carvalho Jr, E. A. R. and Pezzuti, J. C. B. 2010. Hunting of jaguars and pumas in the Tapajós- Arapiuns Extractive Reserve, Brazilian Amazonia. Oryx 44: 610-612.

Chetkiewicz, C. B. and Raygorodetsky, G. 1999. Jaguar Reconnaissance survey in Mamirauá and Amanã Sustainable Development Reserves. Unpublished Report. Wildlife Conservation Society, New York, USA.

Edgaonkar, A. and Chellam, R. 1998. A preliminary study on the ecology of the leopard Panthera pardus fusca in Sanjay Gandhi National Park, Maharashtra. Technical Report, Wildlife Institute of India, Dehradun, India.

Fuller, T. D. 1989. Population dynamics of wolves in north central Minnesota. Wildlife Monograph 105:1-41.

Gaona, P., Ferreras P. and Delibes, M. 1998. Dynamics and viability of a metapopulation of the endangered Iberian lynx (Lynx pardinus) Ecological Monographs 68: 349-370.

Goodrich, J. M., Kerley, L. L., Smirnov, E. N., Miquelle, D. G., McDonald, L., Quigley, H. B., Hornocker, M. G. and McDonald, T. 2008. Survival rates and causes of mortality of Amur tigers on and near the Sikhote-Alin Biosphere Zapovednik. Journal of Zoology 276: 323-329.

Haight, R. G., Mladenoff, D. J. and Wudenven, A. P. 1998. Modelling disjunct gray wolf populations in semi-wild landscapes. Conservation Biology 12: 879-888.

Harmsen, B. J. 2006. The use of camera traps for estimating abundance and studying the ecology of jaguars (Panthera onca). PhD Thesis, University of Southampton, UK.

Henschel, P., Hunter, L., Breitenmoser, U., Purchase, N., Packer, C., Khorozyan, I., Bauer, H., Marker, L., Sogbohossou, E. and Breitenmoser-Wursten, C. 2008. Panthera pardus. In: IUCN 2013. IUCN Red List of Threatened Species. Version 2013.2. <www. 
iucnredlist.org $>$. Downloaded on 18 November 2013.

Ikanda, D. and Packer, C. 2008. Ritual vs. retaliatory killing of African lions in the Ngorongoro Conservation Area, Tanzania. Endangered Species Research 6:67-74.

Jenny, D. 1996. Spatial organization of leopards (Panthera pardus) in Tai National Park, Ivory Coast: is rain forest habitat a tropical haven? Journal of Zoology 240: 427-440.

Joshi, R. and Agarwal, R. 2012. Mortality in the Protected Leopard's Population, Uttarakhand, North India: A Free-Ranging Wildlife Species in Threat. International Journal of Ecosystem 2(4): 44-53.

Karanth, K. U. and Chundawat, R. S. 2002. Ecology of the tiger: implications for population monitoring. In: Karanth, K.U., Nichols, J.D., (Eds.), Monitoring Tigers and their Prey: A Manual for Researchers, Managers and Conservationists in Tropical Asia: Bangalore. Centre for Wildlife Studies, India, pp. 9-21.

Kissui, B. M. 2008. Livestock predation by lions, leopards, spotted hyenas, and their vulnerability to retaliatory killing in theMaasai steppe, Tanzania. Animal Conservation 11:422-432.

Knight, R. R. and Eberhardt, L. L. 1985. Population dynamics of Yelowstone grizzly bears. Ecology 66: 323-334.

McLellan, B., Hovey, F., Mace, R., Woods, J., Carney, D., Gibeau, M., Wakkinen, W. and Kasworm, W. 1999. Rates and causes of grizzly bear mortality in the interior mountains of British Columbia, Alberta, Montana, Washington, and Idaho. Journal of Wildlife Management 63: 911-920.

Mukherjee, S., and Mishra, C., 2001, Predation by leopard Panthera pardus in Majhatal Harsang Wildlife Sanctuary, W. Himalayas. Journal Bombay Natural History Society 98, 267-268.

Newby, I. R. Mills, L. C. Ruth, T. K., Pletscher, D. H., Mitchell, M. S., Quigley, H. B., Murphy, K. M. and DeSimone, R. 2013. Human-caused mortality influences spatial population dynamics: Pumas in landscapes with varying mortality risks. Biological Conservation 159: 230-239.

Nielsen, S. E., Stenhouse, G.B. and Boyce, M.S. 2006. A habitat-based framework for grizzly bear conservation in Alberta. Biological Conservation 130: 217-229.

Noss, R.F., Quigley, H.B., Hornocker, M.G., Merill, T., and Paquet, P.C., 1996, Conservation biology and carnivore conservation in the Rocky Mountains. Conservation Biology 10: 949-963

Nowell, K. and Jackson, P. 1996. Wild Cats: Status Survey and Conservation Action Plan. IUCN/SSC Cat Specialist Group. IUCN, Gland, Switzerland.
Odden, M. and Wegge, P. 2005. Spacing and activity patterns of leopards Panthera pardus in the Royal Bardia National Park, Nepal. Wildlife Biology 11: 145-152.

Packer, C. Brink, H., Kissui, B. B., Maliti, H., Kushnir, H. and Carro, T. 2011. Effects of Trophy Hunting on Lion and Leopard Populations in Tanzania Conservation Biology 25(1): 142- 153.

Ramalho, E. E. 2012. Jaguar (Panthera onca) population dynamics, feeding ecology, human induced mortality, and conservation in the Várzea floodplain forests of Amazonia. PhD Thesis, University of Florida.

Ray, J. C., Hunter, L. T. B. and Zigouris, J. 2005. Setting conservation and research priorities for larger African carnivores. Working paper 24. Wildlife Conservation Society, New York.

Seidensticker, J., Sunquist, M. and McDougal, C. 1990. Leopards living at the edge of the Royal Chitwan National Park, Nepal. Pp 415-423 in J. C. Daniel and J. S. Serrao, eds. Conservation in developing countries: problems and prospects. Proc. Centenary Seminar of the Bombay Natural History Society. Bombay Natural History Society and Oxford University Press, Bombay.

Shah, K. B., Thapa, T. B. and Budha, P. B. 2004. Status survey of the forest Leopard (Panthera pardus Linnaeus, 1758) in Nepal. A Report Submitted to WWF Nepal Program, Kathmandu, Nepal.

Smith, J. L. D. 1993. The role of dispersal in structuring the Chitwan tiger population. Behaviour 124 (3-4): 165-195.

Stahl, P. and Vandel, J. M. 1999. Death and captures of lynx (Lynx lynx) in France (1974-1998). Mammalia 63: 49-59.

Sunquist, M. E. 1981. The social organization of tigers in Royal Chitawan National Park, Nepal. Smithsonian Contributions Zoology 336: 1-98.

Thapa, T. B. 2011. Habitat Suitability Evaluation for Leopard (Panthera pardus) using Remote Sensing and GIS in and around Chitwan national Park, Nepal. PhD Thesis, Saurasthra University, India.

Weaver, J. L., Paquet, P. C. and Ruggiero, L. F. 1996. Resilience and conservation of large carnivores in the Rocky Mountains. Conservation Biology 10: 964-976.

Woodroffe, R. 2001. Predators and people: using human densities to interpret decline of large carnivores. Animal Conservation 3: 165-173.

Woodroffe, R. and Frank, L. G. 2005. Lethal control of African lions (Panthera leo): local and regional population impacts. Animal Conservation 8:91-98.

Woodroffe, R. and Ginsberg, J. R. 1998. Edge effects and the extinction of populations inside protected areas. Science 280: 2126-2128. 